\title{
Variability in per capita oogonia and sporophyte production from giant kelp gametophytes (Macrocystis pyrifera, Phaeophyceae)
}

\author{
Variabilidad de la producción per cápita de oogonios y esporofitos de huiro \\ (Macrocystis pyrifera, Phaeophyceae) \\ VERÓNICA MUÑOZ ${ }^{1}$, MARÍA C. HERNÁNDEZ-GONZÁLEZ ${ }^{1}$, ALEJANDRO H. BUSCHMANN ${ }^{1}$, \\ MICHAEL H. GRAHAM ${ }^{2} \&$ JULIO A. VÁSQUEZ ${ }^{3}$ \\ ${ }^{1}$ Centro de Investigación y Desarrollo en Ambientes y Recursos Costeros (i mar), \\ Universidad de Los Lagos, Casilla 557, Puerto Montt, Chile \\ ${ }^{2}$ Moss Landing Marine Laboratories, 8272 Moss Landing Road, Moss Landing, California 95039, USA \\ ${ }^{3}$ Departamento Biología Marina, Facultad de Ciencias del Mar, Universidad Católica del Norte y \\ Centro de Estudios Avanzados en Zonas Aridas (CEAZA), Coquimbo, Chile \\ Corresponding author: E-mail: abuschma@ulagos.cl
}

\begin{abstract}
Vegetative growth and fertility of kelp gametophytes are thought to be antagonistic, such that most successful kelp recruitment is assumed to result from fertilization of single oogonia released from unicellular female gametophytes. We used laboratory culture experiments to study the effect of temperature and nutrient addition on the per capita production of oogonia and sporophytes from Macrocystis pyrifera female gametophytes. Our results indicate that individual multicellular female gametophytes can give rise to more than one oogonium and that per capita oogonia production significantly increases with the enhancement of culture conditions (i.e., decreased temperature and increased nutrient concentration). Furthermore, the production of multiple oogonia per female often led to the production of multiple sporophytes per female. We discuss the importance of these results relative to variability in $M$. pyrifera life histories (e.g., annual vs. perennial) and their likely ecological and evolutionary consequences.
\end{abstract}

Key words: gametophytes, Macrocystis pyrifera, nutrients, oogonia production, sporophyte production, temperature.

\section{RESUMEN}

El crecimiento vegetativo y la fertilidad de gametofitos de huiros son antagónicos, de modo tal, que un reclutamiento exitoso se obtiene tras la fertilización de un único oogonio liberado por un gametofito femenino unicelular. Se utilizaron técnicas de cultivo de laboratorio para estudiar el efecto que ejerce la temperatura y la adición de nutrientes sobre la producción per cápita de oogonios y esporofitos de Macrocystis pyrifera. Nuestros resultados indican que gametofitos femeninos multicelulares pueden producir más de un oogonio y la producción per cápita incrementa significativamente al modificarse las condiciones de cultivo (por ejemplo disminución de la temperatura e incremento de las concentraciones de nutrientes). La producción de oogonios múltiples por gametofito femenino llevó la mayoría de los casos a una producción múltiple de esporofitos por hembra. Discutimos la importancia de estos resultados en relación a la variabilidad de las historias de vida de $M$. pyrifera (por ejemplo poblaciones anuales versus poblaciones perennes) y sus consecuencias ecológicas y evolutivas.

Palabras clave: gametofitos, Macrocystis pyrifera, nutrientes, producción de oogonios, producción de esporofitos, temperatura.

\section{INTRODUCTION}

It has been generally accepted that the primary pattern of sexual reproduction in kelps (Laminariales, Phaeophyceae) is for settled zoospores to germinate and develop into smallsized gametophytes that produce gametes in the shortest time possible (e.g., Lüning \& Neushul 1978, Kain 1979). In this scenario, female gametophytes are unicellular (or have very few cells at most) and produce one oogonium each (Fritsch 1952, Lüning \& Neushul 1978, Hoffmann et al. 1984, Reed et al. 1988). The number of sporophytes resulting from sexual 
reproduction therefore is not expected to exceed the maximum density of fertile female gametophytes. The development of unicellular female gametophytes that produce single oogonia, however, appears to depend on variability in abiotic factors. Under certain conditions of limiting resources (e.g., low light or low nutrient concentrations), multicellular female gametophytes with multiple oogonia can be observed (e.g., studies with Lessonia nigrescens by Hoffmann \& Santelices 1982, Hoffmann et al. 1984, Ávila et al. 1985); it is unknown whether this pattern only occurs when resources are limiting. If these gametophytes may be capable of producing more sporophytes per capita, this process can have important consequences to kelp population dynamics.

Development of alternative seaweed reproductive strategies that vary according to environmental conditions has received little attention (see review by Santelices 1990). Recently, we demonstrated the importance of different giant kelp (Macrocystis pyrifera) life histories (annual vs. perennial) for regulating recruitment in wave protected and exposed locations in central Chile (Buschmann et al. 2004). We found that, in annual populations where $M$. pyrifera adult sporophyte density decreas tozero in the winter, spring recruitment was enhanced by increasing per capita spore production during a shorter reproductive period than in continuously reproducing perennial populations. Although untested, the production of more than one oogonium per female gametophyte may also increase sexual reproduction success in annual $M$. pyrifera populations; Etcheverry \& Collantes (1978) observed multiple oogonia per female gametophyte in laboratory cultures of Chilean Macrocystis pyrifera. Given only a few reproductive months per year, we hypothesize that any mechanism that enhances fertilization and/or the survival of microscopic stages when macroscopic sporophytes are absent may be advantageous.

In this study, we used laboratory experiments to assess (1) the potential for variability in temperature and nutrient concentration to regulate the size and production of oogonia in female gametophytes of the giant kelp Macrocystis pyrifera, and (2) whether increased oogonia production per female resulted in increased sporophyte production per gametophyte. Furthermore, we tested whether variability in oogonia and sporophyte production was related to the dynamics of adult populations by replicating our experiments using reproductive material from both annual and perennial populations located along protected and exposed coasts, respectively.

\section{MATERIAL AND METHODS}

In July 2002, fertile sporophylls were collected from two subtidal Macrocystis pyrifera populations: Metri and Bahía Mansa (Fig. 1). Metri is a wave-protected region with annual $M$. pyrifera populations, whereas the perennial M. pyrifera populations at Bahía Mansa are exposed to high wave action (Buschmann et al. 2004). Sporophyll samples were packed in plastic bags and transported in ice to the laboratory. The sporophylls were gently brushed and rinsed with sterile filtered $(0.2$ $\mu \mathrm{m})$ seawater to remove epiphytes, and packed with filter paper and aluminum foil for $12 \mathrm{~h}$ at a temperature of $8^{\circ} \mathrm{C}$. After this mild desiccation period, $1 \mathrm{~cm}^{2}$ discs were cut from each fertile sorus and one disc was placed in glass Petri dishes $(5 \mathrm{~cm}$ diameter) to induce sporulation. Immediately after $12 \mathrm{~h}$ of sporulation, for each population, replicate Petri dishes were assigned to each of six orthogonal combinations of temperature $\left(8,15\right.$ and $\left.18{ }^{\circ} \mathrm{C}\right)$ and nutrient concentration (pure seawater and pure seawater plus Provasoli culture medium, McLachlan 1973). The temperature treatments were selected to represent the typical annual range observed at Metri and Bahía Mansa. The resulting average concentrations of swimming zoospores in the Petri dishes were 36,000 zoospores $\mathrm{mL}^{-1}$ for Metri and $47,000 \mathrm{~mL}^{-1}$ for Bahia Mansa. The experiments were carried out in culture chambers under constant conditions: photoperiod of 12:12 $\mathrm{h}$ and a photon flux of 40 umol m $\mathrm{m}^{-2} \mathrm{~s}^{-1}$ provided by 40 Watt fluorescent Phillips tubes; these instantaneous irradiance levels are near those that saturate photosynthesis in both $M$. pyrifera gametophytes and embryonic sporophytes ( $40-70 \mu \mathrm{mol} \mathrm{m} \mathrm{m}^{-2} \mathrm{~s}^{-1}$; Fain \& Murray 1982). The fertile soral discs and initial culture media were discarded after $24 \mathrm{~h}$ and new culture medium was added and changed on a weekly basis. 


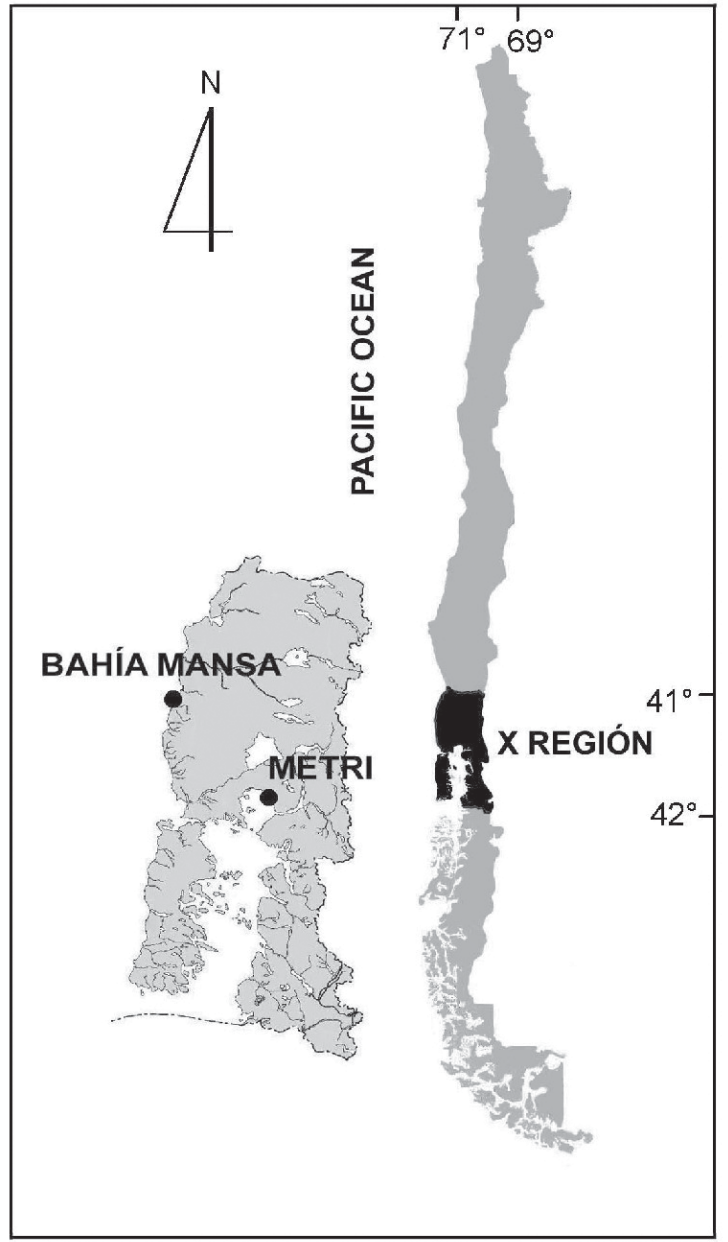

Fig. 1: Map showing the Macrocystis pyrifera sporophyll collection sites in southern Chile: Bahía Mansa (wave exposed) and Metri (wave protected).

Mapa mostrando los lugares de colección de esporofilas de Macrocystis pyrifera en el sur de Chile: Bahía Mansa (sitio expuesto) y Metri (sitio protegido).

Within a few weeks of incubation under even the best conditions (i.e., low temperature and high nutrients), individual multicellular male and female gametophytes were almost perfectly spherical (Fig. 2A). After 30 days of incubation, female gametophytes were counted for three replicates of each of the 12 treatment combinations (i.e., two localities, three temperatures, two nutrient conditions) to determine female gametophyte density (number $\mathrm{mm}^{-2}$ ). Counting was done using an inverted Nikon microscope (brightfield at 20x magnification) attached to a digital camera and an image analyzer (Image-Pro version
4.0); each dish was randomly photographed three times from which the counts were made. Additionally, gametophyte diameter was determined for 12 female gametophytes in each of the 12 treatment combinations using photographs as described above. Finally, after 75 days of incubation we estimated the number of oogonia per female gametophyte, in addition to the number of embryonic sporophytes per female gametophyte in five replicates of each of the 12 treatment combinations. To control for fertility variations over time, random observations were taken every three days to account for different maturation timings during the experiment. As no differences were found, only the total 75 days period data is presented.

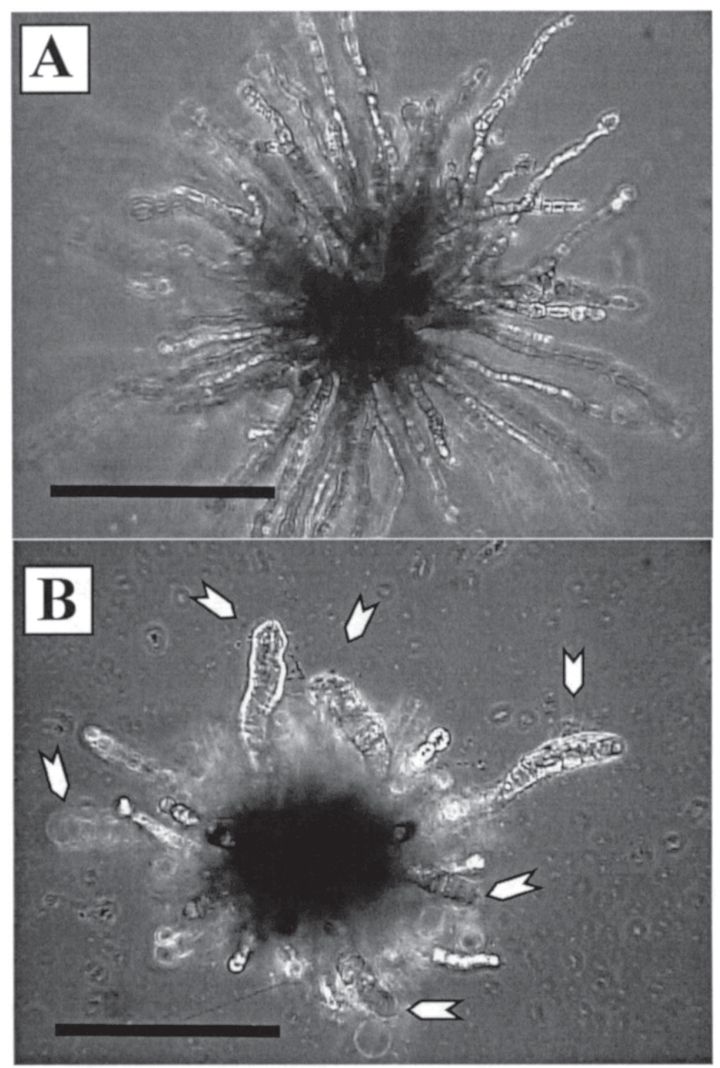

Fig. 2: Photomicrographs of female Macrocystis pyrifera gametophytes: (A) a multicelullar female gametophyte, and (B) a female gametophyte with three (white arrows) sporophytes. Scale bar: $0.1 \mathrm{~mm}$.

Microfotografías de gametofitos femeninos de Macrocystis pyrifera: (A) gametofito multicelulares femeninos, y (B) gametofito multicelular con multiples esporofitos (flechas blancas). Escala: 0,1 $\mathrm{mm}$. 
All data were analyzed using three-way ANOVA (Model I) with Temperature (three levels), Nutrient Concentration (two levels), and Locality (two levels) as fixed factors. Residuals were normal and homoscedastic. Magnitude of effects (variance components) were estimated for all main effects and interactions according to Graham and Edwards (2001). Bonferroni multiple comparisons were done for predetermined contrasts according to Day \& Quinn (1989). We were particularly interested in determining whether significant main effects and interactions were consistent among localities, rather than whether differences existed between localities. All analyses were done using Systat 5.

\section{RESULTS}

The density of female Macrocystis pyrifera gametophytes varied significantly among nutrients and the temperature*nutrient interaction (Fig. 3, Table 1A); among these the temperature*nutrient interaction explained the greatest amount of variability. Female gametophyte densities were significantly greater (1) at $8{ }^{\circ} \mathrm{C}$ relative to 15 and $18{ }^{\circ} \mathrm{C}(\mathrm{P}<$ $0.05)$, and (2) in the presence of nutrients for the Metri population $(\mathrm{P}<0.05)$. The diameter of the female gametophytes varied significantly among localities and nutrient concentrations, as well as the locality*temperature interaction (Fig. 4, Table 1B). Female gametophytes were greater in the presence of nutrient addition; the locality*temperature interaction was due to differences among localities at 8 and $15{ }^{\circ} \mathrm{C}$, Bahía Mansa samples having larger female gametophytes than Metri samples. The number of oogonia produced per female gametophyte differed significantly among all main effects and interactions (Fig. 5, Table 1C). Significant differences, however, were due to treatment effects only for the Bahía Mansa population, in which per capita production of oogonia increased (1) with nutrient additions at 8 and $15{ }^{\circ} \mathrm{C}(\mathrm{P}<0.0001)$, and similarly (2) with decreased temperature when nutrients were present $(\mathrm{P}<0.0001)$. Finally, per capita oogonium production was positively related to the diameter of female gametophytes (simple linear regression: $\mathrm{F}_{1,10}=16.49, \mathrm{P}=0.0023, \mathrm{r}^{2}$ $=0.62$ ).

\section{(A) $8^{\circ} \mathrm{C}$}

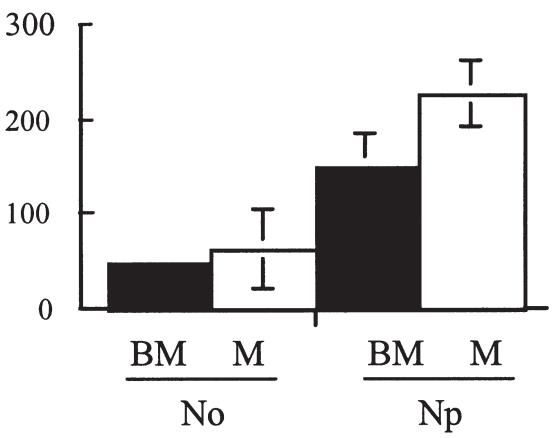

(B) $15^{\circ} \mathrm{C}$

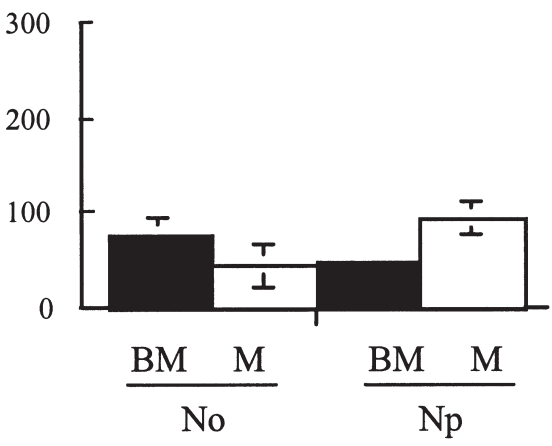

(C) $18^{\circ} \mathrm{C}$

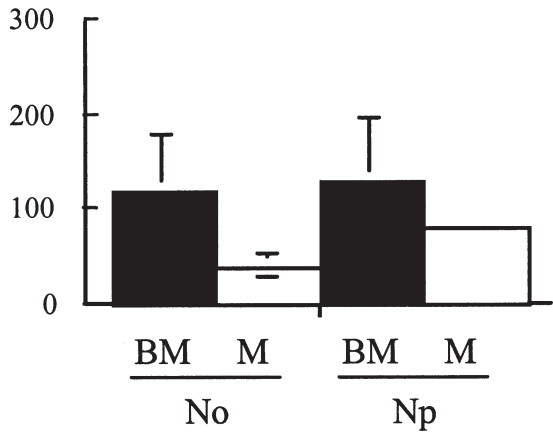

Fig. 3: Effects of temperature, collection locality, and nutrient concentration on female $M a$ crocystis pyrifera gametophyte density (number $\mathrm{mm}^{-2}$ ): (A) $8{ }^{\circ} \mathrm{C}$, (B) $15{ }^{\circ} \mathrm{C}$, and (C) $18{ }^{\circ} \mathrm{C}$; localities: $\mathrm{BM}=$ wave exposed site at Bahía Mansa, $\mathrm{M}=$ wave protected site at Metri; nutrient concentrations: No = filtered seawater, $\mathrm{Np}=$ filtered seawater plus Provasoli culture medium. All data are means \pm SE.

Efecto de la temperatura, sitio de colección, y concentración de nutrientes sobre la densidad de gametofitos femeninos (número $\mathrm{x} \mathrm{mm} \mathrm{mm}^{-2}$ ): (A) $8{ }^{\circ} \mathrm{C}$, (B) $15{ }^{\circ} \mathrm{C}$, y (C) $18{ }^{\circ} \mathrm{C}$; localidades: $\mathrm{BM}=$ sitio expuesto en Bahía Mansa, $\mathrm{M}=$ sitio protegido en Metri; concentración de nutrientes: No = agua filtrada, $\mathrm{Np}=$ agua filtrada con medio Provasoli. Los datos corresponden a medias \pm EE . 


\section{TABLE 1}

Results of three-way Model I ANOVAs testing the effects of collection locality, temperature, and nutrient concentration on various aspects of Macrocystis pyrifera sexual reproduction; $\%$ represents percentage of variance in dependent variables explained by various factors (magnitude of effects) calculated according to Graham \& Edwards (2001)

Resultados de ANDEVA de tres vías Modelo I para verificar los efectos de la localidad de colección, temperatura y nutrientes sobre varios aspectos de la reproducción sexual de Macrocystis pyrifera; (\%) representa el porcentaje de la varianza de variables dependientes explicados por varios factores (magnitud de los efectos) calculados de acuerdo a Graham \& Edwards (2001)

(A) Number of female gametophytes (per $\mathbf{m m}^{-2}$ )

\begin{tabular}{lcccccc}
\hline Factor & Sums of squares & df & Mean square & F-value & P-value & $(\%)$ \\
\hline Locality (L) & 122.877 & 1 & 122.877 & 0.04 & 0.8519 & 0.00 \\
Temperature (T) & 19287.3 & 2 & 9643.64 & 2.79 & 0.0811 & 12.06 \\
Nutrients (N) & 29387.7 & 1 & 29387.7 & 8.52 & 0.0075 & 9.88 \\
L x T & 18322.7 & 2 & 9161.36 & 2.65 & 0.0909 & 11.33 \\
L x N & 7489.46 & 1 & 7489.46 & 2.17 & 0.1537 & 1.54 \\
T x N & 26907.0 & 2 & 13453.5 & 3.90 & 0.0342 & 17.87 \\
L x T x N & 820.492 & 2 & 410.246 & 0.12 & 0.8884 & 0.00 \\
Error & 82821.8 & 24 & 3450.91 & & & 47.32
\end{tabular}

(B) Diameter of female gametophytes

\begin{tabular}{lcccccc}
\hline Factor & Sums of squares & df & Mean square & F-value & P-value & $(\%)$ \\
\hline Locality (L) & 0.16 & 1 & 0.16 & 21.27 & $<0.0001$ & 10.81 \\
Temperature (T) & 0.03 & 2 & 0.02 & 2.26 & 0.1082 & 1.35 \\
Nutrients (N) & 0.09 & 1 & 0.09 & 12.68 & 0.0005 & 6.23 \\
L x T & 0.06 & 2 & 0.03 & 4.29 & 0.0157 & 3.51 \\
L x N & 0.02 & 1 & 0.02 & 2.21 & 0.1396 & 0.64 \\
T x N & 0.02 & 2 & 0.01 & 1.63 & 0.1999 & 0.67 \\
L x T x N & 0.00 & 2 & 0.00 & 0.03 & 0.9753 & 0.00 \\
Error & 0.98 & 132 & 0.01 & & & 76.79
\end{tabular}

(C) Number of oogonia per female gametophyte

\begin{tabular}{lcccccc}
\hline Factor & Sums of squares & df & Mean square & F-value & P-value & $(\%)$ \\
\hline Locality (L) & 10.00 & 1 & 10.00 & 17.48 & 0.0001 & 8.19 \\
Temperature (T) & 27.66 & 2 & 13.83 & 24.17 & $<0.0001$ & 23.04 \\
Nutrients (N) & 21.77 & 1 & 21.77 & 38.04 & $<0.0001$ & 18.41 \\
L x T & 7.42 & 2 & 3.71 & 6.49 & 0.0033 & 5.46 \\
L x N & 2.55 & 1 & 2.55 & 4.46 & 0.0404 & 1.72 \\
T x N & 8.92 & 2 & 4.46 & 7.79 & 0.0012 & 6.76 \\
L x T x N & 8.73 & 2 & 4.37 & 7.63 & 0.0014 & 6.59 \\
Error & 25.75 & 45 & 0.57 & & & 29.83 \\
\hline
\end{tabular}




\section{(A) $8^{\circ} \mathrm{C}$}

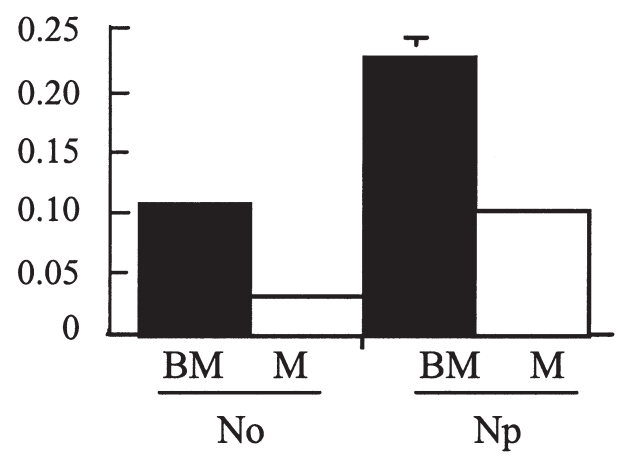

(B) $15^{\circ} \mathrm{C}$

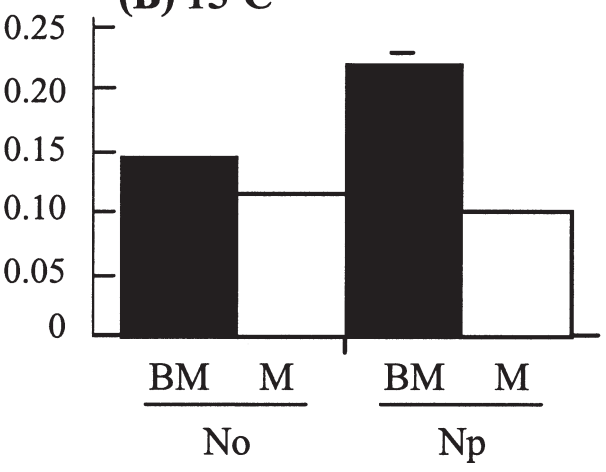

(C) $18^{\circ} \mathrm{C}$

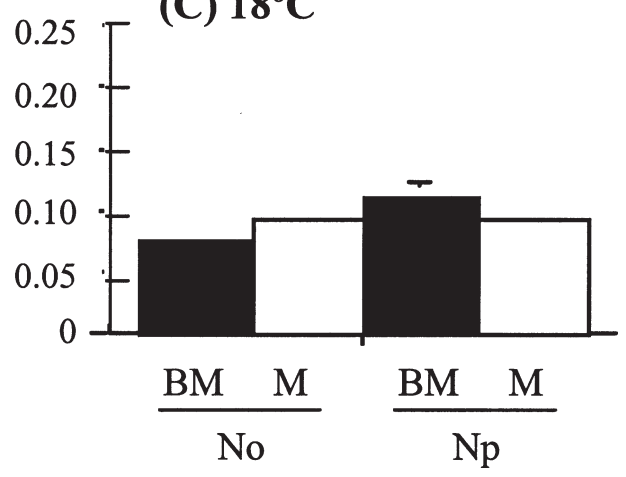

Fig. 4: Effects of temperature, collection locality, and nutrient concentration on the female Macrocystis pyrifera gametophyte diameter (mm): (A) $8^{\circ} \mathrm{C}$, (B) $15^{\circ} \mathrm{C}$, and (C) $18^{\circ} \mathrm{C}$; localities: $\mathrm{BM}=$ wave exposed site at Bahía Mansa, $\mathrm{M}=$ wave protected site at Metri; nutrient concentrations: $\mathrm{No}=$ filtered seawater, $\mathrm{Np}=$ filtered seawater plus Provasoli culture medium. All data are means $\pm \mathrm{SE}$.

Efecto de la temperatura, sitio de colección, y concentración de nutrientes sobre el diámetro de los gametofitos femeninos (mm): (A) $8{ }^{\circ} \mathrm{C}$, (B) $15^{\circ} \mathrm{C}$, y (C) $18^{\circ} \mathrm{C}$; localidad: $\mathrm{BM}=$ sitio expuesto en Bahía Mansa, $\mathrm{M}=$ sitio protegido en Metri; concentración de nutrientes: No = agua filtrada, $\mathrm{Np}=$ agua filtrada con medio Provasoli. Los datos corresponden a medias \pm EE.

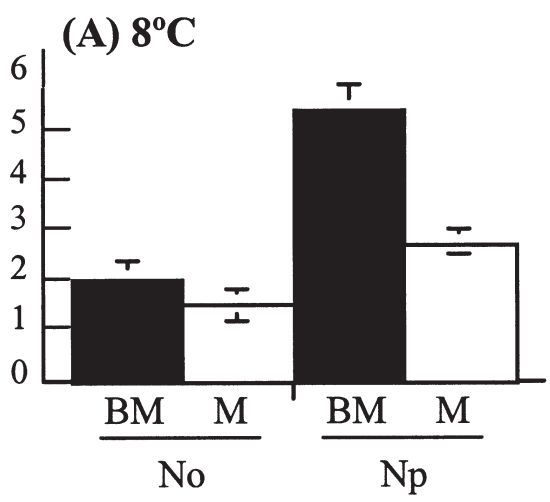

(B) $15^{\circ} \mathrm{C}$

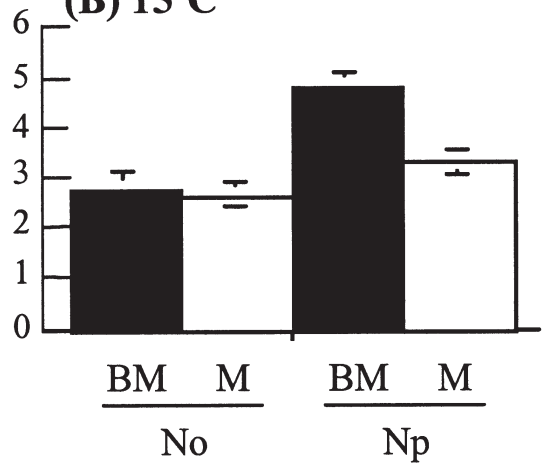

(C) $18^{\circ} \mathrm{C}$

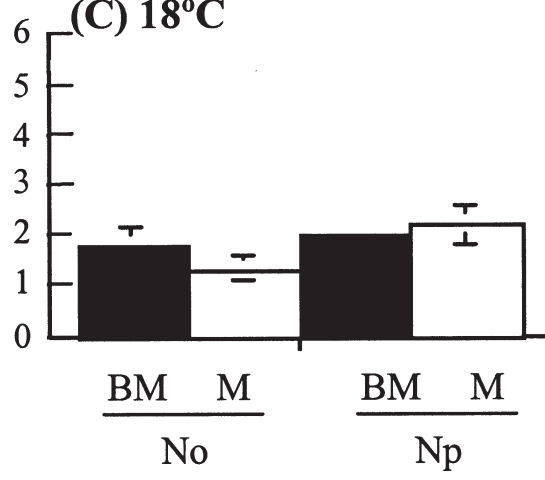

Fig. 5: Effects of temperature, collection locality, and nutrient concentration on the per capita Macrocystis pyrifera oogonia production (number per female gametophyte): (A) $8{ }^{\circ} \mathrm{C}$, (B) $15{ }^{\circ} \mathrm{C}$, and (C) $18{ }^{\circ} \mathrm{C}$; localities: $\mathrm{BM}=$ wave exposed site at Bahía Mansa, $\mathrm{M}=$ wave protected site at Metri. Nutrient concentrations: No $=$ filtered seawater, $\mathrm{Np}=$ filtered seawater plus Provasoli culture medium. All data are means \pm SE.

Efecto de la temperatura, sitio de colección, y concentración de nutrientes sobre el número de oogonios per cápita de gametofitos femeninos (número por gamatofito femenino): (A) $8{ }^{\circ} \mathrm{C}$, (B) $15{ }^{\circ} \mathrm{C}$ y (C) $18{ }^{\circ} \mathrm{C}$; localidades: $\mathrm{BM}=$ sitio expuesto en Bahía Mansa, $\mathrm{M}=$ sitio protegido en Metri; Concentración de nutrientes: No = agua filtrada, $\mathrm{Np}$ = agua filtrada con medio Provasoli. Los datos corresponden a medias \pm EE. 
Fertilization by active anterozoids was observed and sporophyte production failed in 8 of the 12 treatments, precluding statistical analysis of the number of sporophytes produced per gametophyte. For the Metri samples, multiple sporophytes per gametophyte were only observed under low nutrient concentrations at $15^{\circ} \mathrm{C}(\sim 1$ sporophyte/ gametophyte).

Subsequent to the collection of the June sporophyll samples, we found that fertilization success of Metri gametophytes was seasonally dependent (Buschmann et al. 2004), with peak fertilization success occurring a few months prior to the June collection. Fertilization, however, was common for the Bahía Mansa samples, occurring in three of the six temperature-nutrient combinations. In each of these cases, the number of sporophytes per gametophyte (mean \pm SE) always exceeded 1 : low nutrients at $8{ }^{\circ} \mathrm{C}=2.0 \pm 0.0$; low nutrients at $15{ }^{\circ} \mathrm{C}=3.0 \pm 1.5$; high nutrients at $15{ }^{\circ} \mathrm{C}=$ $2.0 \pm 0.5$.

In summary, decreasing temperatures and the addition of nutrients generally led to increased (1) female gametophyte density, (2) female gametophyte size, and (3) per capita production of oogonia. Furthermore, the production of greater than one oogonium per female gametophyte often resulted in greater than one sporophyte per gametophyte (as seen in Fig. 2B).

\section{DISCUSSION}

Recently, studies of kelp population dynamics have focused on processes regulating the fertility, survivorship, and growth of the microscopic life history stages (Deysher \& Dean 1984, 1986, Reed et al. 1988, 1991, Reed 1990, Graham 1996, 1999, Kinlan et al. 2003), as recruitment to macroscopic size appears to be key in controlling variability in kelp population density (Graham et al. 1997). Small unicellular gametophytes can reach fertility in very short periods ( 14 days), whereas multicellular gametophytes may remain sterile for prolonged durations (e.g., Lüning \& Neushul 1978, Kain 1979, Hoffmann \& Santelices 1982, Ávila et al. 1985). Multicellularity is therefore often considered a response to insufficient conditions for gametogenesis; kelp gametophytes cultured in the absence of blue light grow multicellularly and remain sterile indefinitely. Thus, it is generally thought that vegetative growth and fertility of kelp gametophytes have antagonistic tendencies.

We observed the opposite pattern for southern Chilean Macrocystis pyrifera populations. Under some culture conditions (low temperatures, high nutrients, and adequate light), Chilean populations of giant kelp typically yielded large multicellular female gametophytes with high per capita oogonia and sporophyte production rates. In general, this pattern was observed for both annual (Metri) and perennial (Bahía Mansa) populations. Although field studies have yet to be conducted, our results reject the generality of the assumptions that (1) optimal growth conditions yield unicellular female gametophytes and (2) that multicellularity decreases gametophyte fertility. In our case multicellularity is not an artifact as this response has been obtained in almost all culture conditions inclusively in commercial scale Macrocystis pyrifera operations (A. Buschmann unpublished results).

The per capita production of multiple oogonia and ultimately multiple embryonic sporophytes, could have important ecological and evolutionary consequences, especially in spatially and temporally variable environments (e.g., Deysher \& Dean 1986, Dayton et al. 1992, 1999, Reed et al. 1996) as in southern Chile (Buschmann 1992, Vásquez \& Buschmann 1997). When faced with microscale mortality factors (e.g., herbivory, sedimentation, epiphytism, or competition with microalgae), increased per capita production of embryonic sporophytes may increase survivorship. As long as the entire gametophyte is not killed, we hypothesize that increased per capita sporophyte production will enhance recruitment success. Furthermore, successful fertilization of kelp oogonia is dependent on a critical density of male and female gametophytes $\left(\sim 1\right.$ settled spore $\mathrm{mm}^{-2}$, Reed et al. 1991), as antherozoid release and their attraction to eggs is regulated by the concentration of a pheromone released during the emergence of eggs (e.g., Maier et al. 1987). At low gametophyte densities, pheromone may not be sensed by swimming antherozoids. Thus, 
we further hypothesize that increased per capita production of oogonia may raise pheromone concentrations and/or simply provide a more attractive target for swimming antherozoids. Finally, production of multiple oogonia and embryonic sporophytes per gametophyte may also have genetic consequences at the population level. Fertilization of multiple oogonia on the same gametophyte will inherently lead to decreased genetic diversity among resulting embryonic sporophytes relative to that of unicellular female gametophytes that produce a single oogonium. However, this scenario is only evolutionary relevant if more than one embryonic sporophyte from the same gametophyte survive to adult reproductive size; this may be unlikely given the five or more orders-of-magnitude difference in size between kelp gametophytes and reproductive adult sporophytes. These hypotheses await rigorous testing.

Although many of the observed responses of Macrocystis pyrifera sexual reproduction to temperature and nutrient manipulation were common to both annual and perennial populations, some processes (e.g., sporophyte production) were population specific. These results may have important biological significance for these populations with contrasting dynamics. The capacity of $M$. pyrifera to produce multiple sporophytes per gametophytes may have important consequences to kelp population dynamics, especially for annual populations with microscopic stages that remain a long period ( $>3$ months) before they can be recognized as macroscopic recruits in the environment. Furthermore, is there a genetic basis for these population level differences? Recruitment failed when microscopic stages from the perennial $M$. pyrifera population at Bahía Mansa were transplanted to Metri (A. Buschmann unpublished results). This result suggests that either intra-population genetic differences exist for $M$. pyrifera in southern Chile or that acclimatization to such different environmental conditions occurs gradually. Recently, however, Coyer et al. (2001) failed to find significant differences in ITS1 and ITS2 sequences between $M$. pyrifera populations at Bahía Mansa and Metri, suggesting that these are simply different populations within the same species (as appear all Macrocystis sp. populations worldwide, Coyer et al. 2001). The differential response of sexual reproduction to temperature and nutrient availability among annual and perennial $M$. pyrifera populations (this study), as well as those of the Northern Hemisphere comparisons, demonstrate the highly plastic nature of the $M$. pyrifera life history.

Embryonic sporophytes have recently been identified as a potential life history stage allowing for Macrocystis pyrifera dormancy or delayed recruitment (Kinlan et al. 2003). The production of multiple embryonic sporophytes per female gametophyte (this study) may enhance the survivorship of this key life history stage and could be especially important in regions where delayed recruitment is vital to kelp population dynamics; Ladah et al. (1999) suggested that dormancy of microscopic stages was vital to the recovery of some decimated $M$. pyrifera populations. The same may be true for the uniquely annual $M$. pyrifera populations of southern Chile (Buschmann 1992, Buschmann et al. 2004), in which adults disappear for four to five months during late autumn, winter and early spring. Further experiments are necessary to test the consequence of increased per capita sporophyte production to $M$. pyrifera population dynamics.

\section{ACKNOWLEDGEMENTS}

This study was funded by FONDECYT-Chile, grant Nr. 1000044 \& 1010706. We appreciate the critical comments of Daniel Varela, two reviewers and the help of René Espinoza, Luis Filún y Ulises Yagode collecting the fertile material.

\section{LITERATURE CITED}

ÁVILA M, AJ HOFFMANN \& B SANTELICES (1985) Interactions of temperature, photon flux density and photoperiod on the development of microscopic stages of Lessonia nigrescens (Phaeophyta, Laminariales). Revista Chilena Historia Natural 58: 71-82.

BUSCHMANN AH (1992) Algal communities of a waveprotected intertidal rocky shore in southern Chile. In: Seeliger U (ed) Coastal plant communities of Latin America: 91-104. Academic Press, San Diego, California, USA.

BUSCHMANN AH, JA VÁSQUEZ, P OSORIO, E REYES, L FILUN, MC HERNÁNDEZ-GONZÁLEZ \& A VEGA (2004) The effect of water movement, temperature and salinity on abundance and 
reproductive patterns of Macrocystis spp (Phaeophyta) at different latitudes in Chile. Marine Biology 145: 849-862.

DAY RW \& GP QUINN (1989) Comparisons of treatments after an analysis of variance in ecology. Ecological Monographs 59: 433-463.

COYER JA, GJ SMITH \& RA ANDERSEN (2001) Evolution of Macrocystis spp. (Phaeophyceae) as determined by ITS1 and ITS2 sequences. Journal of Phycology 37: 574-585.

DAYTON PK, MJ TEGNER, PE PARNELL \& PB EDWARDS (1992) Temporal and spatial patterns of disturbance and recovery in a kelp forest community. Ecological Monographs 62: 421-445.

DAYTON PK, MJ TEGNER, PB EDWARDS \& KL RISER (1999) Temporal and spatial scales of kelp demography: the role of oceanographic climate. Ecological Monographs 69: 219-250.

DEYSHER LE \& TA DEAN (1984) Critical irradiance levels and the interactive effects of quantum irradiance and dose on gametogenesis in the giant kelp, Macrocystis pyrifera. Journal of Phycology 20: 520-524.

DEYSHER LE \& TA DEAN (1986) In situ recruitment of sporophytes of the giant kelp, Macrocystis pyrifera (L) C.A. Agardh: effects of physical factors. Journal of Experimental Marine Biology and Ecology 103: 41-63.

ETCHEVERRY H \& G COLLANTES (1978) Cultivo artificial de Macrocystis pyrifera (L) C.A. Agardh (Phaeophyta, Laminariales). Anales del Museo Nacional de Historia Natural (Chile) 11: 9-17.

FAIN SR \& SN MURRAY (1982) Effects of light and temperature on net photosynthesis and dark respiration of gametophytes and embryonic sporophytes of Macrocystis pyrifera. Journal of Phycology 18: 92-98.

FRITSCH FE (1952) Structure and reproduction of the algae. Cambridge University Press, Cambridge, United Kingdom. xiv + 939 pp.

GRAHAM MH (1996) Effect of high irradiance on recruitment of the giant kelp Macrocystis (Phaeophyta) in shallow waters. Journal of Phycology 32: 903-906

GRAHAM MH (1999) Identification of kelp zoospores from in situ plankton samples. Marine Biology 135: 709-720.

GRAHAM MH \& MS EDWARDS (2001) Statistical significance versus fit: estimating the importance of individual factors in ecological analysis of variance. Oikos 93: 505-513.

GRAHAM MH, C HARROLD, S LISIN, K LIGHT, JM WATANABE \& MS FOSTER (1997) Population dynamics of giant kelp Macrocystis pyrifera along a wave exposure gradient. Marine Ecology Progress Series 148: 269-279.

HOFFMANN AJ \& B SANTELICES (1982) Effects of light intensity and nutrients on gametophytes and gametogenesis of Lessonia nigrescens Bory
(Pheophyta). Journal of Experimental Marine Biology and Ecology 60: 77-89.

HOFFMANN AJ, M ÁVILA \& B SANTELICES (1984) Interactions of nitrate and phosphate on the development of microscopic stages of Lessonia nigrescens Bory (Phaeophyta). Journal of Experimental Marine Biology and Ecology 78: 177-186.

KAIN J (1979) A view of the genus Laminaria. Oceanography and Marine Biology Annual Review 17: 101-161.

KINLAN BP, MH GRAHAM, E SALA, \& PK DAYTON (2003) Arrested development of giant kelp (Macrocrocystis pyrifera, Phaeophyceae) embryonic sporophytes: a mechanism for delayed recruitment in perennial kelps? Journal of Phycology 39: 47-57.

LADAH LB, JA ZERTUCHE-GONZÁLEZ \& G HERNÁNDEZ-CARMONA (1999) Giant kelp (Macrocystis pyrifera, Phaeophyceae) recruitment near its southern limit in Baja California, after mass disappearance during ENSO 1997-1998. Journal of Phycology 35: 1106-1112.

LÜNING K \& M NEUSHUL (1978) Light and temperature demands for growth and reproduction of Laminarian gametophytes in southern and central California. Marine Biology 45: 297-309.

MAIER I, DG MÜLLER, G GASSMANN, W BOLAND \& L JAENICKE (1987) Sexual pheromones and related egg secretions in Laminariales (Phaeophyta). Zeitschrift Naturforschung, Section C, Biosciences 42: 948-954.

McLACHLAN J (1973) Growth media-marine. In: Stein J (ed) Handbook of phycological methods. Culture methods and growth measurements: 25-51. Cambridge University Press, Cambridge, United Kingdom.

REED DC (1990) The effect of variable settlement and early competition on patterns of kelp recruitment. Ecology 71: 776-787.

REED DC, DR LAUR \& AW EBELING (1988) Variation in algal dispersal and recruitment: the importance of episodic events. Ecological Monographs 58: 321335.

REED DC, M NEUSHUL \& AW EBELING (1991) Role of settlement density on gametophyte growth and reproduction in the kelps Pterygophora californica and Macrocystis pyrifera (Phaeophyceae). Journal of Phycology 27: 361-366.

REED DC, AW EBELING, TW ANDERSON \& M ANGHERA (1996) Differential reproductive responses to fluctuating resources in two seaweeds with different reproductive strategies. Ecology 77 : 300-316.

SANTELICES B (1990) Patterns of reproduction, dispersal and recruitment in seaweeds. Oceanography and Marine Biology Annual Review 28: 177-276.

VÁSQUEZ JA \& AH BUSCHMANN (1997) Herbivorekelp interactions in Chilean subtidal communities: a review. Revista Chilena Historia Natural 70: 41-52. 